\title{
Excursion of The Median, Ulnar and Radial Nerves During the Nerve Gliding Exercises Used in The Orthopedic Physiotherapy: A Cadaveric Study
}

\author{
(DD) Ibrahim Gökhan Duman ${ }^{1}$, (D) Serkan Davut ${ }^{1}$, (iD) Hasan Hallaçeli ${ }^{2}$, (D) Yunus Doğramacı ${ }^{2}$, (D) Vedat Uruç ${ }^{2}$ \\ ${ }^{1}$ Asst. Prof., Hatay Mustafa Kemal University,Faculty of Medicine Department of Orthopedics and Traumatology Hatay, Turkey. \\ 2 Prof., Hatay Mustafa Kemal University, Faculty of Medicine Department of Orthopedics and Traumatology Hatay, Turkey.
}

\section{$\ddot{O z}$}

Ortopedik Fizyoterapide Uygulanan Sinir Mobilizasyon Egzersizleri ile Median, Ulnar ve Radial Sinirlerin Ekskursiyonu: Bir Kadavra Çalıșması

Amaç: Bu çalışmadaki amacımız üst ekstremite pozisyonun değişimi ve eklem hareketlerinden kaynaklanan sinir hareketinin ölçümünü değerlendirmek. Gereç ve Yöntem: On taze insan kadavrasının üst ekstremiteleri, üst ekstremitenin konumlandırılması ile sinirlerin kayma mesafesi arasındaki ilişkiyi tanımlamak için diseke edildi. Radial, medial ve ulnar sinirlerin her biri için literatürde sinir mobilizasyon - germe terapi (SMG) teknikleri bahsedilmektedir. SMG uygulaması ile omuz, dirsek, el bileği ve parmak hareketine bağlı sinir ekskürsiyonu dirsek seviyesinde değerlendirildi. Bașlangıçta ekstremiteler ve baş anatomik pozisyonda konumlandırıldı. Median sinir için ekstremite pozisyonu dirsek ekstansiyonu, önkol supinasyonu, el bileği ve parmak ekstansiyonu idi. Ulnar sinir için üst ekstremite pozisyonu dirsek fleksiyonu, tam önkol pronasyonu ve el bileği ve parmak dorsifleksiyonuydu. Son olarak, dirsek ekstansiyonu, ön kol pronasyonu, el bileği ve parmak palmar fleksiyonu pozisyonunda radial sinirin ekskürsiyonu gözlendi. Bulgular: Ulnar, radyal ve medyan sinir ekskürsiyonu sırasıyla 13.5, 29.75 ve $11.37 \mathrm{~mm}$ idi.

Sonuç: Bu çalışma, omuz, dirsek, el bileği ve parmak eklemlerinin farklı konumlardaki hareketleriyle, radial, median, ulnar sinirlerin longitudinal; ekskürsiyon hareketi gözlenmiștir. SMG teknikleri ortopedi rehabilitasyonunda sinir dokusunun mobilizasyonuna katkı sağlayabilir.

Anahtar Kelimeler: Ulnar Sinir, Radial Sinir, Median Sinir, Fizik Tedavi Teknikleri, Tedavi Sonuçları

\section{Abstract}

\section{Excursion of The Median, Ulnar and Radial Nerves During the Nerve Gliding Exercises Used in The Orthopedic Physiotherapy: A Cadaveric Study}

Objective: The purpose of this study was to assess the measurement of nerve gliding, resulting from joint motion and changes of upper extremity position.

Methods: The upper extremities of ten fresh human cadavers were dissected to delineate relationship between the positioning of upper extremity and gliding distance of nerves. Nerve mobilization - stretching therapy (SMG) techniques are mentioned in the literature for each of the radial, medial and ulnar nerves. Nerve excursion secondary to motion of shoulder, elbow, wrist, and fingers was evaluated at the elbow via SMG application. Initially extremities and the head were positioned with anatomic position. For the median nerve, extremity position was elbow extension, forearm supination, wrist and finger extension. For the ulnar nerve upper extremity position was elbow flexion, full forearm pronation, and wrist and finger dorsiflexion. Finally, the excursion of the radial nerve was observed with the position of elbow extension, forearm pronation, wrist and finger palmar flexion. Results: The ulnar, radial and median nerves excursion were 13.5, 29.75 and $11.37 \mathrm{~mm}$ respectively.

Conclusion: In this study, longitudinal excursion movement of radial, median and ulnar nerves was observed with movements of shoulder, elbow, wrist and finger joints in different positions. SMG techniques can contribute to the mobilization of nerve tissue in orthopedic rehabilitation.

Keywords: Ulnar Nerve, Radial Nerve, Median Nerve, Physical Therapy Techniques, Treatment Outcome

Nasıl Atıf Yapmalı: Duman IG, Davut S, Hallaçeli H, Doğramacı Y, Uruç V. Excursion of The Median, Ulnar and Radial Nerves During the Nerve Gliding Exercises Used in The Orthopedic Physiotherapy: A Cadaveric Study. MKÜ Tıp Dergisi. 2021;12(44):144-148. https://doi.org/10.17944/mkutfd.905206

Sorumlu Yazar/Corresponding Author: Asst. Prof. İbrahim Gökhan Duman 


\section{INTRODUCTION}

The peripheral nervous system has an inherent capacity to tolerate significant limb motion. Longitudinal nerve movement is important because it allows a nerve to adapt to changes in bed length that occur during limb movements. A physiological excursion of the peripheral nerve during motion of the extremities avoids stretching or kinking of the nerves $(1,2)$. These properties are frequently referred to as nerve biomechanics (3-5). If there was insufficient nerve motion, functional activities that necessitate these upper limb motions might expose the upper extremity nervous system to extreme mechanical stress. The ability of peripheral nerves to stretch and slide is thought to be of paramount significance to maintain best neural function (6). Peripheral nerve compression may interrupt the ability of the nerve to stretch and slide. Prolonged compression causes sequelae of intraneural events that may finally lead to impaired nerve sliding (7).

If the median, ulnar, and radial nerves do not have adequate capacity to glide with the shoulder abduction, elbow extension/flexion, forearm pronation/supination, wrist and finger extension/flexion, the nerve may be exposed to excessive tension during activity of daily living such as bathing, dressing, toileting, transferring, continence, and feeding, which may contribute to movement induced neuropathic symptoms (8).

Median, ulnar and radial nerve excursion at the elbow and wrist associated with upper extremity motion have been studied previously $(9,10)$. There are cadaveric studies (9-14) ultrasonographic studies (15), and intraoperative studies (16). Additionally, some studies have examined the effect of neural mobilization exercises on nerve mechanics in cadavers $(17,18)$. The main mechanism associated with clinical improvements after neural mobilization therapy remain uncertain (19). There are several hypotheses that have been postulated to explain the nerve excursion mechanism $(7,17,18,20)$. The difference in nerve excursion during different types of nerve gliding exercises has been studied by two different methods including sliders and tensioners. Sliders use combinations of normal physiological joint movements to encourage nerve excursion $(18,18,20)$. Tensioners utilize combinations of extreme stretching joint movements that lengthen the nerve bed from both ends to elongate the neural connective tissues (18).

To our knowledge there are only few cadaveric studies which evaluated the nerve excursion. However, there is no cadaveric study which assessed the nerve excursion during the nerve mobilization positions used during the clinically applied orthopedic physiotherapy techniques (6).

The purpose of this study was to evaluate the impact of changes in position and motion of upper extremity during the physical orthopedic rehabilitation programs on the median, ulnar and radial nerves gliding's.

\section{MATERIALS AND METHODS}

Ten fresh cadaver specimens (10 right arms) were dissected (age range, 35-47 years; 10 male) in the same day after death. All specimens had full range of motion at the elbow with no noticeable bony deformities. Exclusion criteria were previous surgery of upper extremity, any soft tissue problems in the upper extremity.

The ethical board of the university endorsed this study. All joints of upper extremity were passively mobilized before the dissection. After passive mobilization, dissections were accomplished by the same experienced hand surgeon.

The median nerve was exposed with minimum disruption of the surrounding soft tissues at the flexion crease at the level of the medial epicondyle. Lacertus was not loosened. The ulnar nerve was exposed without opening the cubital tunnel at the elbow via a medial approach, from $5 \mathrm{~cm}$ proximal to $2 \mathrm{~cm}$ distal to the medial epicondyle. The radial nerve was exposed proximal to the elbow before it bifurcated. (Figure 1) The lateral intermuscular septum was not widened. The nerves appeared healthy and did not sublux in any of the specimens. Nerve excursion associated with motion of the shoulder, elbow, wrist, and fingers (measured by a meter) was assessed at the elbow.

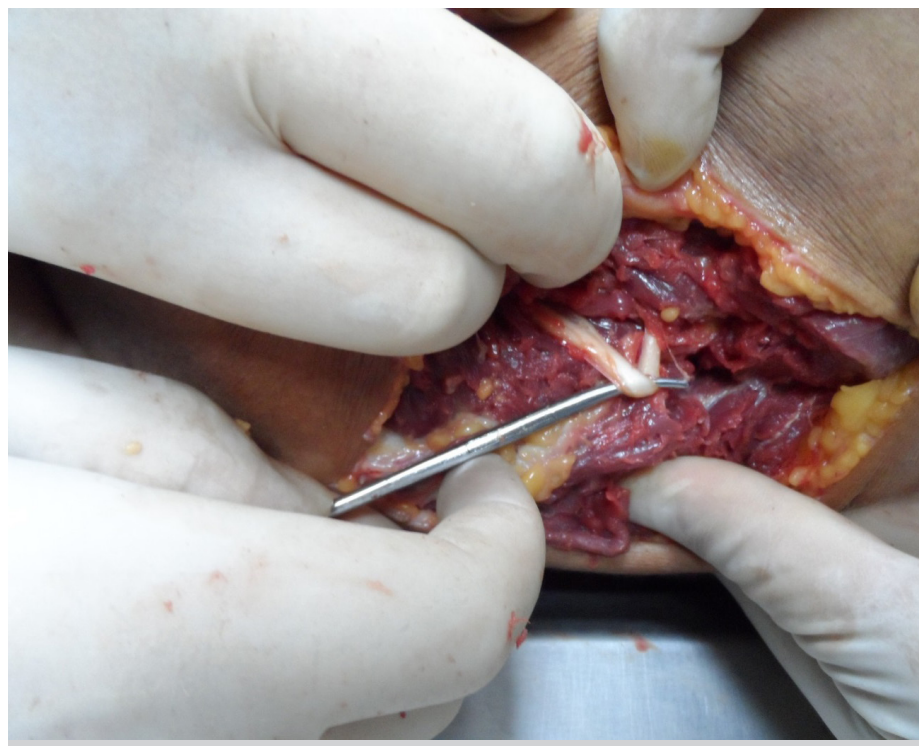

Figure 1. The radial nerve was exposed proximal to the elbow before it bifurcated.

The first position for all nerves was (anatomic positions) with the neck in neutral position face oriented straight forward, the shoulder at $0^{\circ}$ of abduction, arms aligned to the frontal plane with elbow joint extended, palms facing forwards. The starting position in the hand was with the metacarpophalangeal, proximal interphalangeal and distal interphalangeal joints all at $0^{\circ}$. 
The second position for the ulnar nerve was with the shoulder at $90^{\circ}$ of abduction, the elbow at full flexion, the forearm in full pronation, wrist at full extension and all the metacarpophalangeal, proximal interphalangeal and distal interphalangeal joints all at full extension (Figure 2).

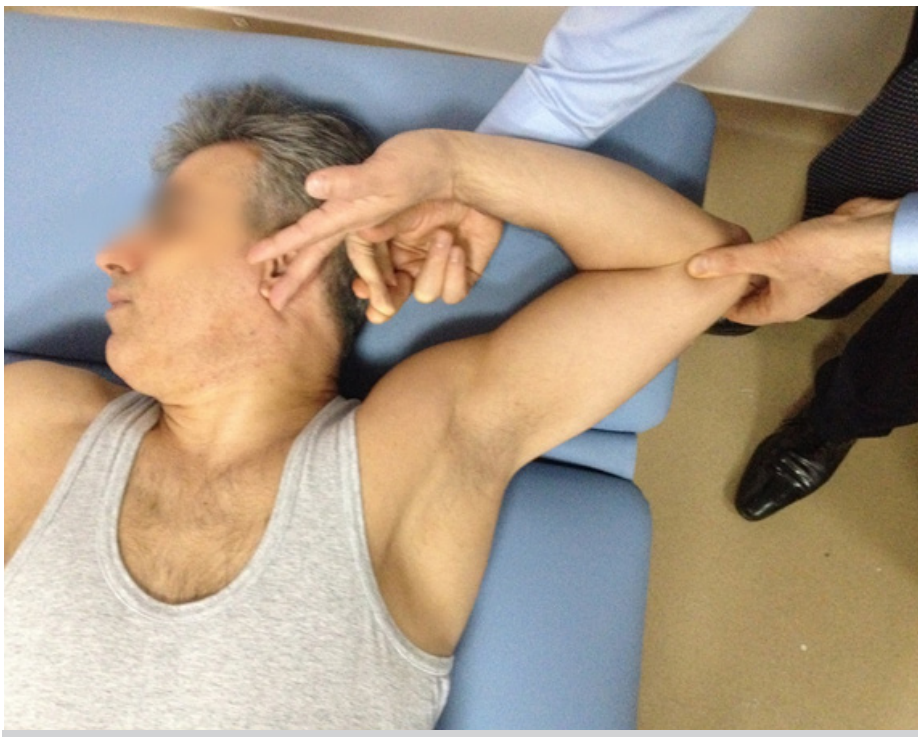

Figure 2. The extremity position for mobilization of ulnar nerve.

The second position for radial nerve was the neck in lateral flexion position face oriented straightforward the shoulder at $90^{\circ}$ of abduction, the elbow at full extension, the forearm at full pronation, wrist and all fingers at full flexion (Figure 3).

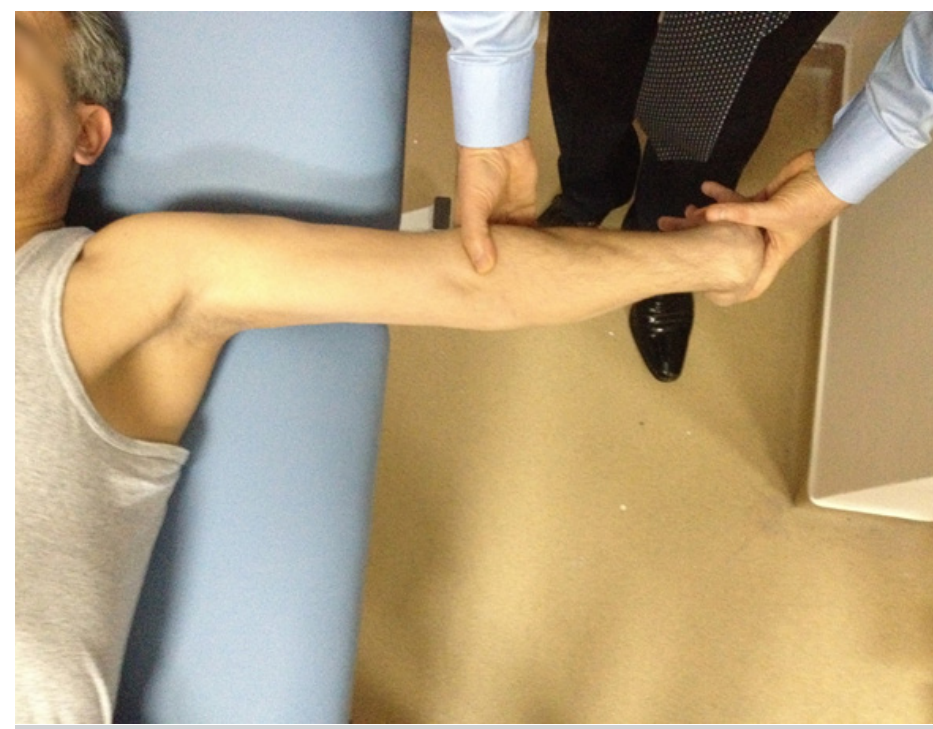

Figure 3. The extremity position for mobilization of radial nerve.

The second position for median nerve was the neck in lateral flexion position face oriented straightforward the shoulder at $90^{\circ}$ of abduction, the elbow at full extension, the forearm at full supination, wrist and all fingers at full extension and abduction (Figure 4).

A Kirschner wire was placed in the humerus $5 \mathrm{~cm}$ above the medial epicondyle, a metallic vascular clip was secured

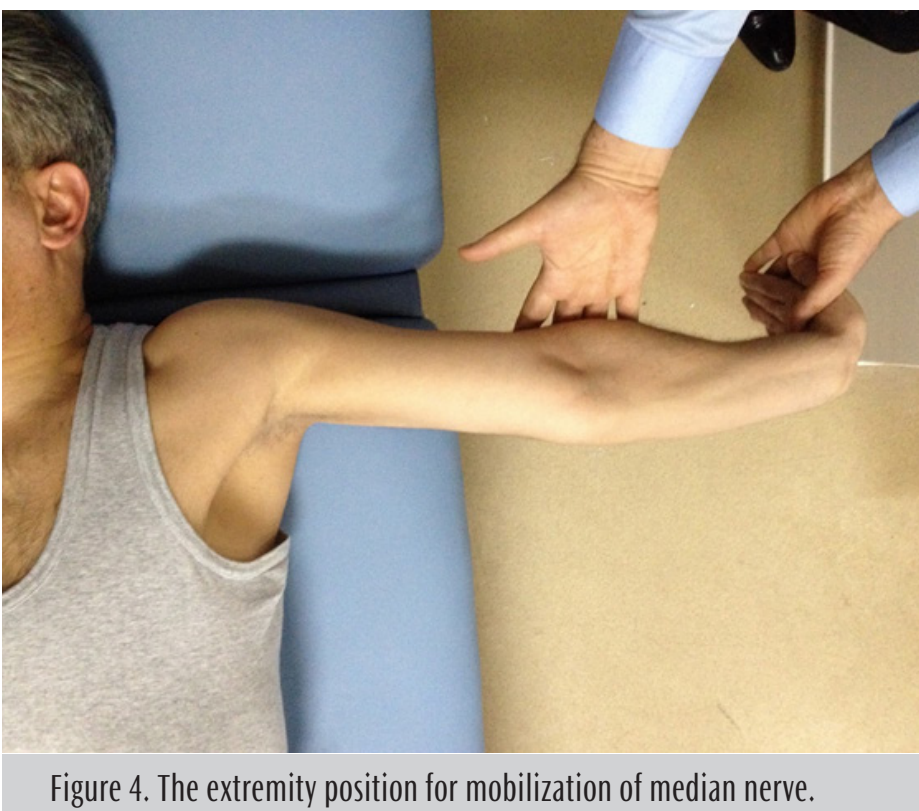

to the studied nerves at the same level of the $\mathrm{K}$ wire. The gliding in millimeters was measured as the distance between the $\mathrm{K}$ wire and stapler in the anatomic or first position and the second position as mentioned above for each nerve. All measurement was recorded manually by the same researcher. The amount of nerve excursion was measured in millimeters with a tape measure.

\section{RESULTS}

The ulnar, radial and median nerves excursion were 13.5, 29.75 and $11.37 \mathrm{~mm}$ respectively. Nerve excursion was evaluated at the elbow level which has defined nerve mobilization treatment position for each nerve in the literature (Table 1).

\begin{tabular}{|l|c|c|}
\hline \multicolumn{1}{|c|}{$\begin{array}{c}\text { Table 1. Excursion of the nerves in the upper } \\
\text { extremity }\end{array}$} \\
\hline Nerve $(\mathrm{n}=10)$ & Mean value (mm) & Min-max (mm)values \\
\hline Median nerve & 11.37 & $9-21$ \\
\hline Ulnar nerve & 13.5 & $29-7$ \\
\hline Radial nerve & 29.75 & $25-36$ \\
\hline
\end{tabular}

\section{DISCUSSION}

Nerve gliding or mobilization is among orthopedic physiotherapy rehabilitation methods. It has been used in the management of certain pathologies like CTS, back pain, epicondylitis and thoracic outlet syndrome (20).

Previous studies have shown that nerve stretching techniques will increase the mobility of the peripheral nerves in the extremity by decreasing the perineural adhesions and contribute muscle power and decrease of the pain sensation $(20,22,23)$. The relation between the joint motion and the 
changes of the morphologic, physiologic and physical behaviors of the peripheral nerves has been studied previously $(1,7,9,12,16,20,23,24)$. Most of the aforementioned studies were clinical research which explain the clinical effectiveness of nerve mobilization $(13,23)$. The mechanical (enhanced nerve excursion), physiological and central effects (reduction of dorsal horn and supraspinal sensitization) of nerve mobilizations have been studied previously $(5,25)$. The clinical effectiveness of the nerve mobilization techniques in orthopedic physiotherapy has been studied previously $(20,21)$. However, the amount of nerve excursion during these mobilization techniques is unknown.

Thus, the nerve excursion was the mainstay of the current study. We found that passive changes in the joint positions of upper extremity (simulating the physiotherapy techniques) will result in a total excursion of $11.37 \mathrm{~mm}$ of median, 13.5 $\mathrm{mm}$ of ulnar and $29.75 \mathrm{~mm}$ of the median nerve.

In a clinical research in healthy individuals, Ellis et al (25) has studied the sciatic nerve excursion using ultrasound technique. They found that sciatic nerve excurses approximately $1 \mathrm{~cm}$ with knee extensions. In another experimental study in rats, Boyd et al (5) (using ultrasound), has reported that sciatic nerve will excurse $10 \mathrm{~mm}$ during the straight leg raising test. Hough et al (23) in a clinical study including patients with a diagnosis of CTS, has shown that median nerve will approximately excurse $8 \mathrm{~mm}$ on the wrist level. Grewal et al (14) in cadaveric study using $\mathrm{x}$-ray documentation, has shown that mean ulnar nerve excursion was $14 \mathrm{~mm}$.

Wright et al (10) has investigated the excursion of nerves around the elbow joint. They found median nerve excurse differently with motion of shoulder, elbow, wrist and fingers. The median nerve excursions were 35.4, 19.6, 5.6 and 9,7 mm with motions of shoulder, elbow, wrist and fingers respectively.

In two other and similar cadaveric studies by Wright et al $(9,13)$, the radial nerve median excursion values were 4.1, 8.8, and $0.2,0.1 \mathrm{~mm}$ with motions of shoulder, elbow, wrist and fingers respectively. For the ulnar nerve excursions were 0.64 , 0.23, 13.58 and $5.97 \mathrm{~mm}$ with motions of shoulder, elbow, wrist and fingers respectively.

In this study we found that maximum excursion was significantly higher than $13.58 \mathrm{~mm}$. However, we measured the excursion during a multiplanar combined joint motion whereas in the Wright's studies measurements were for uniplanar joint mobilizations $(9,10,13)$.

These cadaveric studies which has been conducted by Wright et al $(10,13)$ has shown that maximum excursion for median nerve were recorded during the shoulder abduction motion, for radial nerve the highest excursion was recorded during elbow extension, and for ulnar nerve it was during the wrist extension.

In this study we found that median nerve excursion was in accordance with that recorded by Wright et al (10) however our excursion values of ulnar and radial nerve were higher than that recorded by Wright et al $(9,13)$. These results were secondary to combination motions of all joints at the same time. These findings may explain the superiority and advantages of orthopedic physiotherapy gliding techniques on the nerve excursions.

A limitation of this study was the small number of the cadavers. Another limitation was that all cadavers were male so the differences between genders were not studied.

\section{CONCLUSION}

Multi-planar combined joint mobilization techniques will result in higher nerve excursion than uniplanar mobilization techniques and should be considered in the orthopedic rehabilitation of upper extremity.

\section{ACKNOWLEDGEMENT}

Peer-Review

Externally Peer Reviewed

Conflict of Interest

The authors declare that they have no conflict of interests regarding content of this article.

Financial Support

The Authors report no financial support regarding content of this article.

Ethical Declaration

Ethical approval was obtained from the Mustafa Kemal University, Medical Faculty Clinical Research Ethics Committee with date 14.02.2013 and number 2013-29, and Helsinki Declaration rules were followed to conduct this study.

\section{REFERENCES}

1. Millesi H, Zoch G, Rath T. The gliding apparatus of peripheral nerve and its clinical significance. Ann Hand Surg 1990; 9: 8797. https://doi.org/10.1016/S0753-9053(05)80485-5

2. Lundborg G, Dahlin LB. Anatomy, function, and pathophysiology of peripheral nerves and nerve compression. Hand Clin 1996; 12: 185-193. https://doi.org/10.1016/s07490712(21)00303-6

3. Grewal R, Xu J, Sotereanos DG, Woo SL. Biomechanical properties of peripheral nerves. Hand Clin 1996; 12: 195-204. https://doi.org/10.1016/S0749-0712(21)00304-8

4. Topp KS, Boyd BS. Structure and biomechanics of peripheral nerves: nerve responses to physical stresses and implications for physical therapist practice. Phys Ther 2006; 86: 92-109. https://doi.org/10.1093/ptj/86.1.92 
5. Boyd BS, Puttlitz C, Gab J, Topp KS. Strain and Excursion in the rat sciatic during a modified straight leg raise are altered after traumatic nerve injury. J Orthopaedic Res 2005; 23: 764-770. https://doi.org/10.1016/j.orthres.2004.11.008

6. Muller M, Tsui D, Schnurr R, Biddulph-Deisroth L, Hard J, Macdermid JC. Effectiveness of Hand Therapy Interventions in Primary Management of Carpal Tunnel Syndrome: A Systematic Review. J Hand Ther 2004; 17 : 210-228. https:// doi.org/10.1197/j.jht.2004.02.009

7. Brown C, Gilbert K, Brismee JM, Sizer P, James C, Smith P. The effects of neurodynamic mobilization on fluid dispersion within the tibial nerve at the ankle: an unembalmed cadaveric study. J Man Manip Ther 2011; 19: 26-34. https://doi.org/10.1 179/2042618610Y.0000000003

8. Jepsen JR, Thomsen G. Prevention of upper limb symptoms and signs of nerve afflictions in computer operators: The effect of intervention by stretching. J Occup Med Toxicol 2008; 7: 3:1. https://doi.org/10.1186/1745-6673-3-1

9. Wright TW, Glowczewskie F JR, Cowin D, Wheeler DL. Radial nerve excursion and strain at the elbow and wrist associated with upper-extremity motion. J Hand Surg Am 2005; 3: 990996. https://doi.org/10.1016/j.jhsa.2005.06.008

10. Wright TW, Glowczewskief, Wheeler D, Miller G, Cowin D. Excursion and strain of the median nerve. J Bone Joint Surg Am 1996;78 :1897-1903.https://doi.org/10.2106/00004623199612000-00013

11. Wilgis EF, Murphy R. The significance of longitudinal excursion in peripheral nerves. Hand Clin 1986; 2: 761-766. https://doi. org/10.1016/S0749-0712(21)00622-3

12. Bay BK, Sharkey NA, Szabo RM. Displacement and strain of the median nerve at the wrist. J Hand Surg 1997; 22: 621-627. https://doi.org/10.1016/\$0363-5023(97)80118-9

13. Wright TW, Glowczewskie F JR, Cowin D, Wheeler DL. Ulnar nerve excursion and strain at the elbow and wrist associated with upper extremity motion. J Hand Surg Am 2001; 26: 655662. https://doi.org/10.1053/jhsu.2001.26140

14. Grewal R, Varitimidis SE, Vardakas DG, Fu FH, Sotereanos DG. Ulnar nerve elongation and excursion in the cubital tunnel after decompression and anterior transposition. J Hand Surg Br 2000; 25: 457-460. https://doi.org/10.1016/S02667681(00)80012-1

15. Dilley A, Greening J, Lynn B, Leary R, Morris V. The use of cross-correlation analysis between high-frequency ultrasound images to measure longitudinal median nerve movement. Ultrasound Med Biol 2001; 27: 1211-1218. https://doi. org/10.1016/S0301-5629(01)00413-6
16. Mclellan DL, Swash M. Longitudinal sliding of median nerve during movements of the upper limb. J Neurol Neurosurg Psychiatry 1976; 39: 566-570. https://doi.org/10.1136/ jnnp.39.6.566

17. Coppieters MW, Alshami AM. Longitudinal excursion and strain in the median nerve during novel nerve gliding exercises for carpal tunnel syndrome. J Orthop Res 2007; 25: 972-980. https://doi.org/10.1002/jor.20310

18. Coppieters MW, Butler DS. Do 'sliders' slide and 'tensioners' tension? An analysis of neurodynamic techniques and considerations regarding their application. Man Ther 2008; 13: 213-221. https://doi.org/10.1016/j.math.2006.12.008

19. Brown CL, Gilbert KK, Brismee JM, Sizer PS, Roger James C, Smith MP. The effects of neurodynamic mobilization on fluid dispersion within the tibial nerve at the ankle: an unembalmed cadaveric study. J Man Manip Ther 2011; 19: 2634. https://doi.org/10.1179/2042618610Y.0000000003

20. Beneciuk JM, Bishop MD, George SZ. Effects of upper extremity neural mobilization on thermal pain sensitivity: a shamcontrolled study in asymptomatic participants. J Orthop Sports Phys Ther 2009; 39: 428-438. https://doi.org/10.2519/ jospt.2009.2954

21. Oskay D, Meric A, Kirdi N, Firat T, Ayhan A, Leblebicioğlu G. Neurodynamic Mobilization In The Conservative Treatment Of Cubital Tunnel Syndrome: Long-Term Follow-Up of 7 Cases. J Manipulative Physiol Ther 2010; 33: 156-63. https:// doi.org/10.1016/j.jmpt.2009.12.001

22. Rozmaryn LM, Dovelle S, Rothman ER, Gorman K, Olvey $\mathrm{KM}$, Bartko JJ. Nerve and tendon gliding exercises and the conservative management of carpal tunnel syndrome. J Hand Ther 1998; 11: 171-179. https://doi.org/10.1016/S08941130(98)80035-5

23. Hough AD, Moore AP, Jones MP. Reduced Longitudinal Excursion of Median Nerve in Carpal Tunnel Syndrome. Arch Phys Med Rehabil. 2007; 88: 569-576. https://doi. org/10.1016/j.apmr.2007.02.015

24. Clark WL, Trumble TE, Swiontkowski MF, Tencer AF. Nerve tension and blood flow in a rat model of immediate and delayed repairs. J Hand Surg 1992; 17: 677-687. https://doi. org/10.1016/0363-5023(92)90316-H

25. Ellis RF, Hing WA, Mcnair PJ: Comparison of Longitudinal Sciatic Nerve Movement With Different Mobilization Exercises: An In Vivo Study Utilizing Ultrasound Imaging J Orthop Sports Phys Ther 2012; 42: 667-675. https://doi.org/10.2519/ jospt.2012.3854 